INOBIS: Jurnal Inovasi Bisnis dan Manajemen Indonesia

Volume 1, Nomor 3, Juni 2018

Joeliaty; Yevis Marty Oesman

\title{
Evaluasi Kepuasan Konsumen Terhadap Pelayanan Perizinan di Kota Bandung
}

\author{
Joeliaty \\ joeliaty@unpad.ac.id \\ Yevis Marty Oesman \\ yevismarty@yahoo.com \\ Departemen Manajemen Dan Bisnis FEB Unpad
}

\begin{abstract}
Abstrak
Era otonomi menuntut setiap pemerintah daerah mandiri dan kreatif mencari sumbersumber pembiayaan serta aktif mencari berbagai peluang yang bisa dijadikan sumber pemasukan kas daerah. Kemauan Pemerintah Daerah dalam menciptakan iklim usaha yang bersahabat melalui kemudahan proses perizinan serta berbagai kebijakan yang akomodatif merupakan daya tarik bagi para penanam modal baik dari dalam maupun investor asing. Tujuan dari kegiatan ini adalah untuk melakukan pengawasan dan evaluasi terhadap sistem pelayanan perijinan di Kota Bandung sebagai bagian dari implementasi e-government bidang perijinan serta merumuskan langkah-langkah peningkatan kinerja perijinan. Kajian ini akan dilakukan melalui pengumpulan data sekunder dan primer (survey) yang dilakukan dengan wawancara tokoh (responden) kunci di antaranya pengguna (user) pelayanan perijinan dan pejabat di SKPD pemberi perijinan di Kota Bandung.Hasil dari kajian ini bahwa Layanan kinerja yang belum efektif kinerjanya dilihat dari tingkat kepentingan dan harapan, melalui prosedur layanan, persyaratan perizinan, kejelasan petugas, layanan, kedisiplinan petugas, tanggung jawab, kemampuan layanan, kecepatan, keadilan mendapatkan pelayanan, kesopanan dan keramahan layanan.
\end{abstract}

Kata Kunci : Kepuasan konsumen, Pelayanan Perizinan, Aparat SKPD

\section{Pendahuluan}

\subsection{Latar Belakang}

Berdasarkan hasil kajian Komite Pemantau Pelaksanaan Otonomi Daerah (KPPOD), saat ini masih banyak daerah yang menilai keberhasilan otonomi daerah adalah dengan meningkatnya PAD. Tinggi rendahnya PAD digunakan sebagai parameter untuk mengukur keberhasilan dari pelaksanaan otonomi daerah. Target peningkatan PAD ini seringkali memicu munculnya berbagai kebijakan yang kontraproduktif (counterproductive) terhadap iklim usaha dan investasi. Padahal iklim investasi yang kondusif pasti dapat meningkatkan kegiatan ekonomi, baik berskala besar maupun kegiatan ekonomi kerakyatan sehingga mendongkrak kemampuan pemda, swasta dan pengguna.Kemauan Pemerintah Daerah dalam menciptakan iklim usaha yang bersahabat melalui kemudahan proses perizinan serta berbagai kebijakan yang akomodatif merupakan daya tarik bagi para penanam modal baik dari dalam maupun investor asing. Namun demikian, "kemudahan" bagi para investor dan pengusaha dalam rangka menciptakan iklim usaha yang kondusif haruslah tetap dijaga dampak sosial dan lingkungan yang terjadi. Keberpihakan kepada investor bukan berarti semua jenis usaha layak diizinkan, apalagi investasi asing. Di samping itu, perizinan harus juga memperhatikan fungsi 
INOBIS: Jurnal Inovasi Bisnis dan Manajemen Indonesia

Volume 1, Nomor 3, Juni 2018

Joeliaty; Yevis Marty Oesman

pengendalian selain menjalankan fungsi pelayanan publik yang diperlukan oleh pengguna, mulai dari pelayanan dalam bentuk pengaturan ataupun pelayanan-pelayanan lain dalam rangka memenuhi kebutuhan pengguna. Iklim investasi kondusif terjadi jika pemerintah, swasta dan pengguna umum sama-sama dapat mengambil keuntungan atas keberadaan sebuah investasi. Pendapatan pajak Pemerintah Daerah meningkat, pelaku usaha memperoleh laba tinggi dan tenaga kerja terserap sehingga mengurangi jumlah pengangguran. Kondisi ideal ini dapat terjadi jika ada pola kemitraan antar ketiga pihak di atas. Membangun iklim investasi daerah yang kondusif tidak bisa terlepas dari sistem informasi pasar nasional maupun internasional.

Pelayanan publik sering dilihat sebagai representasi dari eksistensi birokrasi pemerintahan, karena hal itu bersentuhan langsung dengan tuntutan kebutuhan pengguna. Filosofi dari pelayanan publik menempatkan rakyat sebagai subyek dalam penyelenggaraan pemerintahan (Rachmadi, 2008). Pemerintah Daerah dan Dewan Perwakilan Rakyat Daerah (DPRD) harus menyadari bahwa terjadi persaingan ketat antar daerah dalam memperebutkan investasi baru. Pemerintah Daerah yang mampu membuat daerahnya menarik untuk investasi baru akan banyak didatangi investasi. Sebaliknya, Pemerintah Daerah yang daerahnya justru tidak menarik bagi investasi, jangankan masuknya investasi baru, investasi yang telah ada saja di daerah itu besar kemungkinan akan keluar atau pindah ke daerah lain. Secara keseluruhan jumlah perizinan yang dikeluarkan oleh Pemda Kota Bandung berjumlah 160 jenis perizinan yang tersebar di Satuan Kerja Perangkat Daerah (SKPD) dan Kecamatan. Namun sebagian besar pelayanan perizinan di Kota Bandung dipusatkan pada dua SKPD yaitu BPPT (Badan Pelayanan Perizinan Terpadu) dan Dishub (Dinas Perhubungan). Dinas Perhubungan merupakan Dinas Daerah yang menyelenggarakan sebagian urusan pemerintahan dan pelayanan umum di bidang perhubungan, salah satu fungsinya yaitu Pembinaan dan pelaksanaan tugas operasional di bidang Perhubungan yang meliputi lalu lintas dan parkir, angkutan dan terminal, sarana dan operasional. Untuk Dishub kota Bandung, jenis layanan izin yang masih dikeluarkan melalui Dishub adalah izin trayek taksi dan uji KIR. Sedangkan BPPT (Badan Pelayanan Perizinan Terpadu) merupakan SKPD penyelenggaraan pelayanan perizinan yang proses pengelolaannya mulai dari tahap permohonan sampai ke tahap terbitnya dokumen. Jenis izin yang diberikan Badan Pelayanan Perizinan Terpadu kota Bandung yaitu sebanyak 27 jenis layanan perizinan yang diberikan kepada calon pengguna (masyarakat). Seiring dengan jalannya proses pelayanan, terdapat permasalahan yaitu adanya temuan oleh Ombudsman mengenai kinerja yang lambat dan tidak sesuai dengan ketepatan yang telah berlaku yaitu 14 hari kerja serta adanya praktik percaloan dalam proses perizinan dari mulai tahap awal hingga tahap penyelesaian. Oleh karena itu dalam rangka meningkatkan perbaikan pelayanan publik, pemerintah perlu melakukan proses evaluasi terhadap instansi-instansi, yang mendapat banyak keluhan dari pengguna. Berbagai keluhan pengguna secara nasional telah ditampung dan ditindaklanjuti oleh Ombudsman Republik Indonesia. Ombudsman Republik Indonesia adalah lembaga negara di Indonesia yang mempunyai kewenangan mengawasi penyelenggaraan pelayanan publik yang diselenggarakan oleh penyelenggara negara.Dalam hal perizinan guna mendukung iklim usaha yang kondusif, perlu dilakukan evaluasi yang memperhitungkan penerapan Sistem Manajemen Mutu (ISO 9001 : 2008) pelayanan perizinan terkait persyaratan, kebutuhan sumber daya serta pencapaian sasaran mutu.

Perlu diketahui apakah IKM sesuai Kepmen PAN tersebut telah dijadikan indikator dalam kinerja pelayanan perizinan di Kota Bandung, serta bagaimana kepuasan pengguna Kota Bandung secara umum berkaitan dengan pelayanan perizinan di Kota Bandung. 
INOBIS: Jurnal Inovasi Bisnis dan Manajemen Indonesia

Volume 1, Nomor 3, Juni 2018

Joeliaty; Yevis Marty Oesman

\subsection{Maksud dan Tujuan}

Maksud dari pelaksanaan kegiatan ini adalah untuk menyusun sebuah evaluasi mengenai tingkat kepuasan terhadap pelayanan perizinan yang dilakukan oleh Pemerintah Kota Bandung sebagai bahan pengembangan peningkatan kinerja perizinan dan optimalisasi kebijakan dalam menciptakan iklim usaha kondusif di Kota Bandung. Tujuan dari kegiatan ini adalah untuk melakukan pengawasan dan evaluasi terhadap sistem pelayanan perizinan di Kota Bandung sebagai bagian dari implementasi e-government bidang perizinan serta merumuskan langkahlangkah peningkatan kinerja perizinan.

\section{Kajian Pustaka}

Perusahaan, Organisasi ataupun Pemerintah adalah pihak yang menghasilkan produk atau jasa yang ditawarkan kepada konsumennya atau masyarakat. Dalam hal ini Pemerintah menawarkan jasa kepada masyarakat. Jasa atau pelayanan adalah setiap kegiatan atau kinerja yang ditawarkan oleh satu pihak kepada pihak yang lain, yang secara prinsip intangible dan tidak menyebabkan perpindahan kepemilikan apapun. (Kotler dan Keller. 2012; 378).

Pelayanan publik adalah segala kegiatan pelayanan yang dilaksanakan penyelenggara pelayanan publik sebagai upaya pemenuhan kebutuhan penerima pelayanan maupun pelaksanaan ketentuan peraturan perundang-undangan. Penyelenggara pelayanan Publik adalah Instansi Pemerintah. Unit penyelenggara pelayanan publik adalah unit kerja pada Instansi pemerintah yang langsung memberikan pelayanan kepada penerima pelayanan public. Sementara, Pemberi pelayanan publik adalah pejabat/pegawai instansi pemerintah yang melaksanakan tugas dan fungsi pelayanan public sesuai dengan peraturan perundang-undangan. Penerima pelayanan publik adalah orang, masyarakat, instansi pemerintah dan badan hukum yang menerima pelayanan dari innstansi pemerintah. (Pedoman Umum Penyelenggaraan Pelayanan Publik. 2003)

Dalam Pedoman Umum ini pun dijelaskan Hakekat pelayanan publik, adalah pemberian pelayanan prima kepada masyarakat yang merupakan perwujudan kewajiban aparatur Negara sebagai abdi masyarakat. Pelayanan publik yang Prima dalam arti memenuhi harapan dan kebutuhan baik bagi pejabat maupun penerima pelayanan.Selanjutnya pelayanan publik yang prima dijelaskan dalam Asas Pelayanan Publik berdasarkan KepMen no. 63/Kep/M.PAN/7/2003 tentang .Pedoman Umum Penyelenggaraan Pelayanan Publik yang meliputi: transparansi, akuntbilitas, kondisional, partisipastif, persamaan hak dan kesemimbangan. Jasa memiliki karakteristik yang berbeda dengan produk. Jasa adalah sesuatu yang memiliki sifat, intangibility, inseparability, variability, dan perishability (Kotler dan Keller. 2012; 380). Dengan memahami karakteristik jasa tersebut, maka akan dihadapi kendala untuk mengetahui apakah kualitas jasa atau pelayanan yang diberikan sudah memenuhi harapan dan keinginan konsumen atau masyarakat. Apakah konsumen atau masyarakat sudah dapat merasakan kepuasan atas layanan yang diberikan. Indeks Kepuasan Masyarakat adalah tingkat kepuasan masyarakat dalam memperoleh pelayanan yang merupakan perwujudan kewajiban aparatur Negara sebagai abdi masyarakat. (Pedoman Umum Penyelenggaraan Pelayanan Publik. 2003). IKM ini dapat dijadikan sebagai alat evaluasi dari pelayanan publik yang diberikan kepada masyarakat. 
INOBIS: Jurnal Inovasi Bisnis dan Manajemen Indonesia

Volume 1, Nomor 3, Juni 2018

Joeliaty; Yevis Marty Oesman

\section{Metode Penelitian}

Tujuan penelitian ini adalah untuk mengetahui bahwa Indeks kepuasan Masyarakat (IKM) telah dilaksanakan dengan baik dan mengetahui tingkat kepuasan masyarakat terhadap pelayanan perijinan di kota Bandung, maka dilakukan penelitian yang bersifat deskriptif. Penelitian deskriptif dilakukan untuk memperoleh gambaran tentang kepuasan atas pelayanan perijinan. Oleh karenanya dikumpulkan data, baik primer maupun sekunder. Data primer dikumpulkan dengan metode survey melalui wawancara dengan bantuan alat berupa daftar pertanyaan (quetioner) tentang kepuasan masyarakat terhadap kepuasan pelayanan perijinan. Sumber data primer selain dikumpulkan melalui survey, juga dilakukan FGD dengan beberapa tokoh kunci diantaranya pengguna jasa pelayanan perijinan (user) dan pejabat di SKPD pemberi perijinan. Seluruh masyarakat yang datang untuk mendapatkan pelayanan pada keenam jenis perijinan di kota Bandung merupakan populasi penelitian yaitu 8447 responden. Sedangkan Penentuan ukuran sampel berdasarkan perhitungan Slovin (Husein Umar, 2002) sebanyak 100 respomden. Untuk mengetahui tingkat kepuasan masyarakat kota Bandung terhadap keenam jenis pelayanan perijinan, maka dilakukan analisis dengan menggunakan Diagram Kartesius terhadap 14 indikator kepuasan. Diagaram kartesius dibentuk oleh 2 (dua) garis Kepentingan/Harapan dan Kinerja pelayanan perijinan. Diagram ini menunjukkan 4 kuadran, semua indikator akan tersebar pada keempat kuadran tersebut.

\section{Hasil dan Pembahasan}

Kepuasan pelayanan perizinan diukur oleh 14 indikator, yaitu; 1. Prosedur pelayanan, 2. Persyaratan pelayanan, 3. Kejelasan petugas pelayanan, 4.Kedisiplinan petugas pelayanan, 5.Tanggung jawab petugas pelayanan, 6.Kemampuan petugas pelayanan, 7.Kecepatan pelayanan, 8.Keadilan mendapatkan pelayanan, 9. Kesopanan dan keramahan petugas, 10.Kewajaran biaya pelayanan, 11.Kepastian biaya pelayanan, 12.Kepastian jadwal pelayanan, 13.Kenyamanan lingkungan, dan 14.Keamanan pelayanan. Masing-masing indikator diukur tingkat harapan, kepentingan dan kinerjanya menurut penilaian pengguna layanan perizinan.

Karakteristik pengguna berdasarkan jenis Unit Layanan Izin adalah 26\% pengguna Pelayanan Pembuatan Surat Izin Usaha Perdagangan (SIUP). Hal ini mengindikasikan bahwa di Kota Bandung pertumbuhan usaha dapat memberikan kontribusi pada PAD yang besar. Hal ini juga menunjukkan pekerjaan pengguna layanan perizinan mayoritas adalah wirausaha (61\%),

\subsection{Analisis Kepuasan Pengguna Pelayanan Perizinan Di Kota bandung}

Dimensi penelitian berdasarkan Keputusan Menteri Pendayagunaan Aparatur Negara (Kepmen PAN) Nomor: KEP/25/M.PAN/2/2004 yang mencantumkan 14 indikator pelaksanaan Indeks Kepuasan Pengguna (IKM). Tanggapan pengguna mengenai IKM meliputi : kemudahan prosedur pelayanan, kemudahan persyaratan pelayanan, kejelasan petugas pelayanan, kedisiplinan petugas pelayanan, tanggung jawab petugas pelayanan, kemampuan petugas pelayanan, kecepatan petugas pelayanan, keadilan mendapatkan pelayanan, kesopanan dan keramahan petugas pelayanan, kewajaran biaya pelayanan, kepastian biaya pelayanan, kepastian jadwal pelayanan, kenyamanan lingkungan pelayanan dan keamanan pelayanan.

Berdasarkan ulasan di atas, maka dapat dilakukan evaluasi kepuasan pengguna dengan mengukur atau membandingkan harapan, kepentingan dengan kinerja yang dirasakan. Dengan demikian untuk mengukur kepuasan pengguna terhadap pelayanan perizinan di kota 
INOBIS: Jurnal Inovasi Bisnis dan Manajemen Indonesia

Volume 1, Nomor 3, Juni 2018

Joeliaty; Yevis Marty Oesman

Bandung, dapat dilakukan evaluasi tingkat harapan, kepentingan dan kinerja dari 14 indikator pelaksanaan Indeks Kepuasan Masyarakat/ Pengguna (IKM).

\subsection{Analisis Kinerja dan Kepentingan Pengguna Terhadap Pelayanan Perizinan.}

Untuk mengetahui Kinerja dan Kepentingan atas Pelayanan Perizinan di Kotga Bandung, telah disajikan dalam bentuk Gambar Diagram Kartesius yang menggambarkan posisi indikator - indikator dilihat dari sudut tingkat kinerja yang dirasakan oleh pengguna dan tingkat kepentingan pengguna terhadap indikator tersebut.

Gambar Diagram Kartesius terdiri dari 4 (empat) kuadran. Kuadran I adalah kuadran yang menunjukkan posisi indikator - indikator yang dinilai tingkat kepentingannya rendah, namun kinerja yang dirasakan oleh pengguna adalah tinggi atau di atas rata-rata. Ada 4 indikator yang berada dalam kuadran ini, yaitu: (1) kejelasan petugas pelayanan, (2) kesopanan dan keramahan petugas pelayanan, (3) kenyaman dan (4) indikator keamanan. Hal ini menujukkan Pengguna merasakan petugas telah memberikan pelayanan informasi yang jelas, sopan dan ramah dalam melayani pengguna, Pengguna merasa kantor instansi pelayanan cukup nyaman dan aman untuk bertransaksi, namun semua itu bagi pengguna dianggap kurang penting atau kurang menjadi priotas bagi pengguna.

Selanjutnya kuadran II, yaitu kuadran yang menunjukkan posisi indikator yang memiliki tingkat kinerja di atas rata-rata dan tingkat kepentingan juga di atas rata-rata. Indikator tersebut adalah; (1) tanggunjawab petugas pelayanan, (2) Kemampuan Petugas Pelayanan, (3) Kewajaran Biaya Pelayanan dan (4) Kepastian Biaya. Keempat indikator tersebut dinilai oleh pengguna sudah memiliki kinerja yang baik dan indikator tersebut juga merupakan indikator yang dianggap memiliki tingkat kepentingan tinggi bagi pengguna, sehingga instansi pemberi pelayanan perizinan dituntut untuk selalu memberikan pelayanan yang prima. Pengguna sangat menginginkan tanggungjawab petugas dalam memberikan pelayanan perizinan dan hal ini tentunya menuntut kemampuan dari petugas pelayanan perizinan yang handal. Kewajaran dan kepastian biaya pelayanan perizinan juga memiliki tingkat kepentingan yang tinggi, mengingat pengguna dapat mempersiapkan dana yang harus dikeluarkan, dengan adanya kepastian biaya dan kewajaran angkanya tentunya akan membantu pengguna dalam mengalokasikan dana yang mereka miliki.

Selanjutnya Kuadran III, yaitu kuadran yang menggambarkan posisi indikator yang berada pada tingkat kepentingan dan tingkat kinerja yang rendah. Dari hasil penelitian ternyata tidak ada indikator yang berada diposisi ini. Artinya tidak ada indikator Pelayanan Pengguna yang dinilai tidak penting dan kinerja yang tidak baik. 
INOBIS: Jurnal Inovasi Bisnis dan Manajemen Indonesia

Volume 1, Nomor 3, Juni 2018

Joeliaty; Yevis Marty Oesman

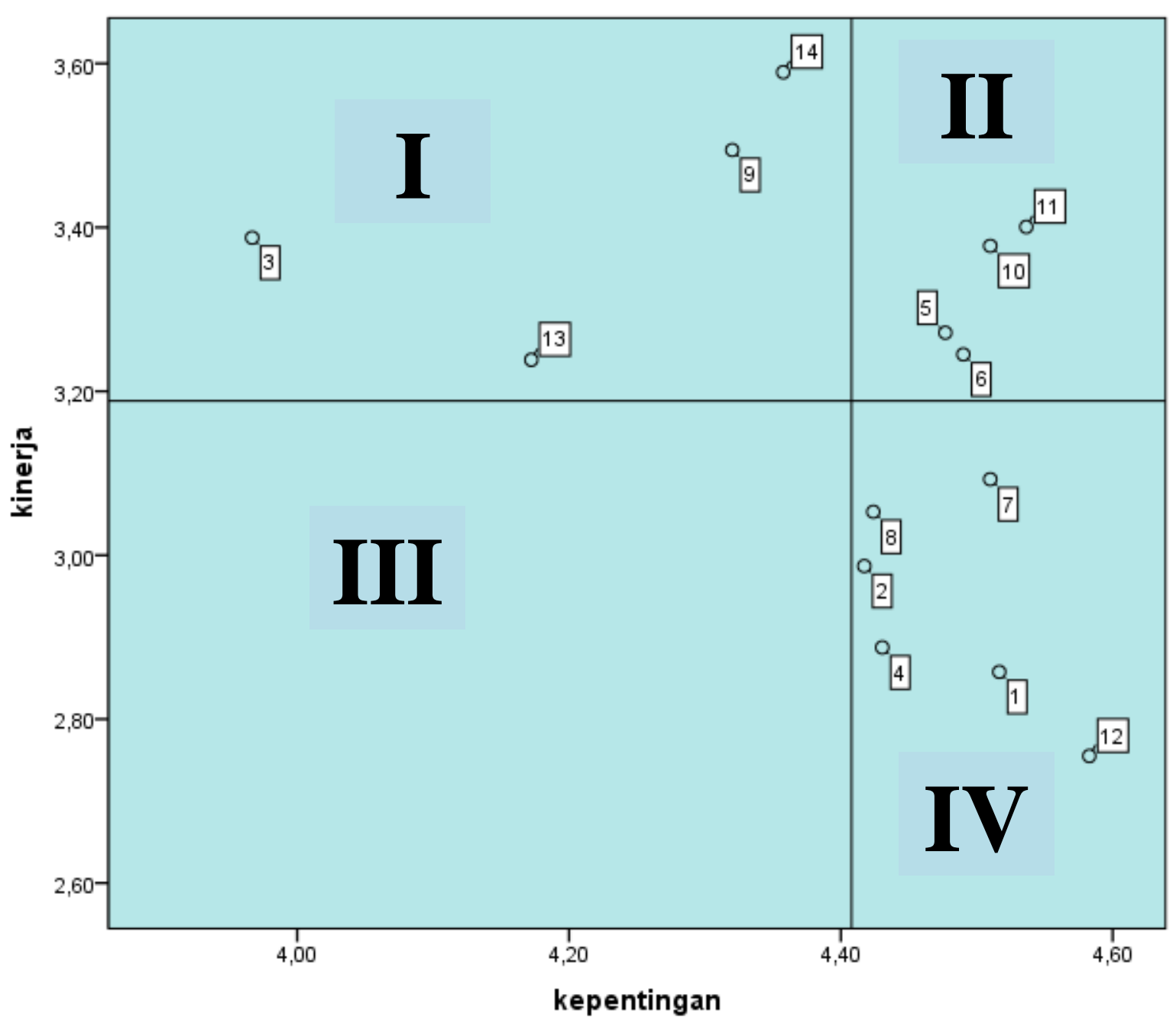

Grafik 4.1 Kepentingan dan Kinerja Pelayanan Perizinan

Kuadran terakhir adalah kuadran IV, yaitu kuadran yang menunjukkan posisi indikator yang memiliki tingkat kepentingan tinggi namun kinerja yang dirasakan pengguna masih rendah. Indikator yang berada pada posisi ini menuntut petugas pelayanan perizinan untuk benar-benar memperhatikannya. Indikator tersebut adalah. (1) prosedur pelayanan, (2) persyaratan pelayanan, (3) kedisplinan petugas pelayanan, (4) Kecepatan petugas pelayanan, (5) keadilan mendapatkan pelayanan dan (6) kepastian jadwal pelayanan. Pengguna sebagai pengguna jasa pelayanan perizinan menginginkan kemudahan dan kejelasan prosedur pelayanan perizinan dan persyaratan yang jelas merupakan hal yang sangat penting, namun kadangkala pengguna tidak mendapatkan kejelasan dan kemudahan dari alur atau prosedur pelayanan, serta persyaratan yang tidak begitu jelas atau konsisten. Demikian pula dengan inikator kedispilinan dan kecepatan petugas pelayanan perijianan yang dinilai penting oleh Pengguna kota Bandung. Dengan kedisiplinana dan kecepatan akan memberikan kepastian dan kepercayaan pada pengguna. Demikian pula dengan indikator keadilan mendapatkan pelayanan dan kepastian jadwal pelayanan. Kedua indikator ini akan lebih meningkatkan kepercayaan pengguna terhadap pelayanan perizinan, karena dengan adanya keadilan dalam pemberian pelayanan perinjinan dan jadwal yang jelas, maka pengguna akan lebih jelas kapan mereka akan mendapatkan giliran untuk dilayanani. Namun kinerja yang diterima oleh pengguna, bahwa pelayanan yang diberikan belum memberikan keadilan dan jadwal yang tidak 
INOBIS: Jurnal Inovasi Bisnis dan Manajemen Indonesia

Volume 1, Nomor 3, Juni 2018

Joeliaty; Yevis Marty Oesman

jelas, petugas yang sering tidak tepat dalam memberikan jadwal pelayanan, atau sering tidak tepat dengan waktu atau jadwal yang telah dijanjikan.

\subsection{Analisis Kinerja dan Harapan Pengguna Terhadap Pelayanan Perizinan.}

Untuk mengetahui kepuasan pengguna pelayanan perizinan, dapat dilihat dari kinerja yang dirasakan pengguna dan membandingkannya dengan harapan pengguna terhadap pelayanan perizinan. Untuk menganalisis kepuasan tersebut dilakukan dengan analiasa diagram kartesius, seperti nampak pada gambar 4.2.

Kuadran I menunjukkan posisi indikator yang berada pada kinerja yang tinggi sementara harapan dari pengguna terhadap indikator tersebut rendah, Posisi ini mengindikasikan bahwa pengguna merasa sangat puas. Indikator tersebut adalah; (1) kejelasan petugas pelayanan, (2) kemampuan petugas pelayanan dan (3) kenyamanan. Nampaknya pengguna sudah paham dengan informasi yang dijelaskan oleh petugas, sehingga pengguna tidak mengharapkan penjelasan yang terlalu berlebihan dan pengguna pun tidak begitu berharap dengan kenyamanan pelayana, karena yang diharapkan adalah kecepatan pelayanan, sehingga pengguna tidak ingin meluangkan waktu yang lama.

Kuadram II adalah kuadran yang menggambarkan posisi indikator yang berada pada tingkat harapan yang tinggi juga tingkat kinerja yang tinggi. Pada posisi ini pengguna merasakan kepuasan. Indikator yang dinilai pengguna telah memberikan kepuasan adalah; (1) tanggung jawab petugas pelayanan, (2) kesopanan dan keramahan petugas pelayanan, (3) kewajaran biaya pelayanan, (4) kepastian biaya dan (5) keamanan. Kelima indikator ini telah memberikan kinerja yang baik, sesuai dengan harapan pengguna, sehingga petugas dituntut untuk dapat mempertahankan kualitas pelayanaannya, sehingga pengguna akan merasa puas dan meningkatkan kepercayaan pengguna terhadap petugas pelayanan perizinan yang pada akhirnya akan membentuk brand image yang baik terhadap instansi pelayanan perizinan. 
INOBIS: Jurnal Inovasi Bisnis dan Manajemen Indonesia

Volume 1, Nomor 3, Juni 2018

Joeliaty; Yevis Marty Oesman

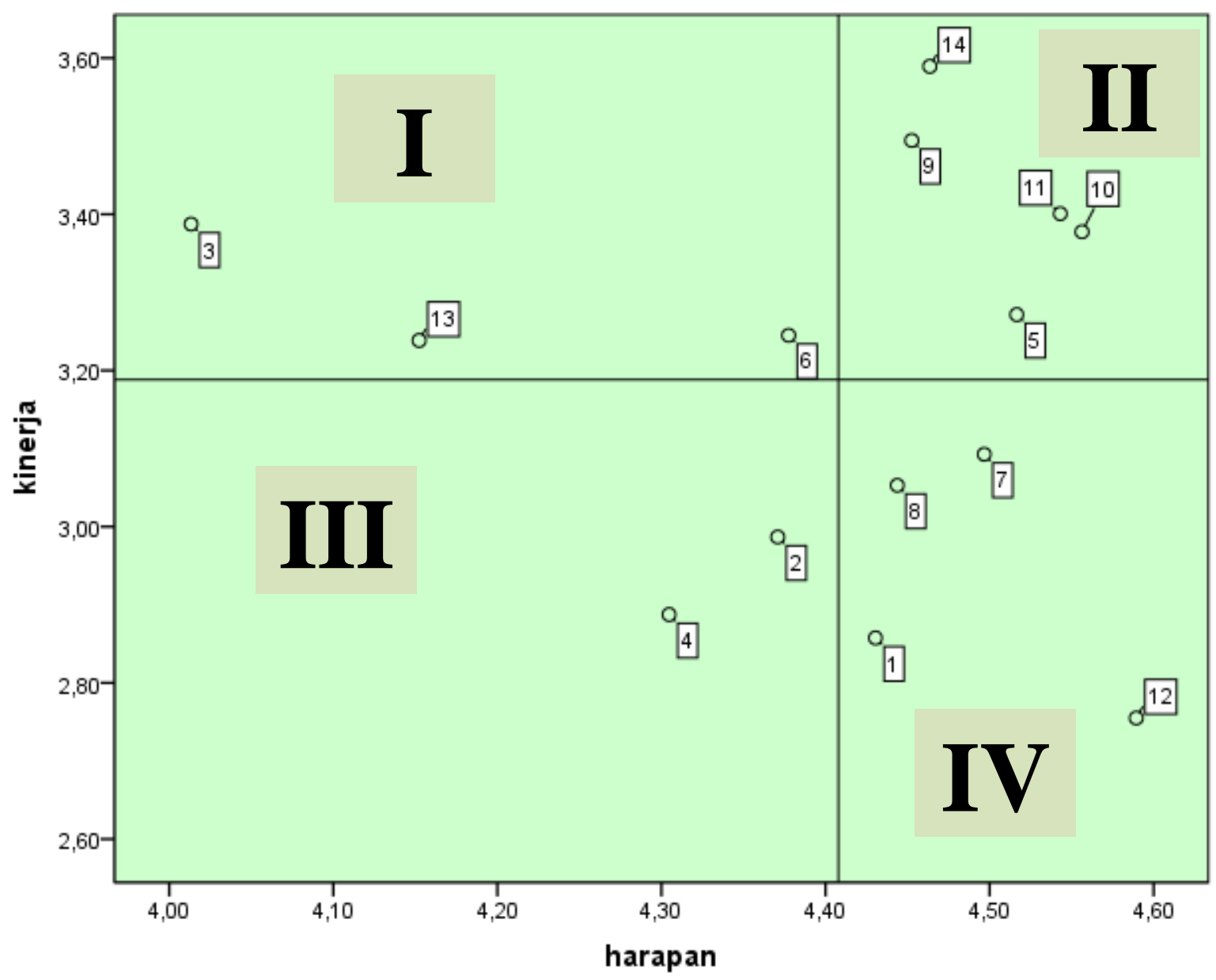

Grafik 4.65 Diagram Kartesius Antara Harapan dan Kinerja

Keterangan

\begin{tabular}{|r|l|}
\hline Kode & Indikator \\
\hline 1 & Prosedur Pelayanan \\
\hline 2 & Persyaratan Pelayanan \\
\hline 3 & Kejelasan Petugas Pelayanan \\
\hline 4 & Kedisiplinan Petugas Pelayanan \\
\hline 5 & Tanggung jawab Petugas Pelayanan \\
\hline 6 & Kemampuan Petugas Pelayanan \\
\hline 7 & Kecepatan Petugas Pelayanan \\
\hline 8 & Keadilan mendapatkan Pelayanan \\
\hline 9 & Kesopanan dan keramahan Petugas Pelayanan \\
\hline 10 & Kewajaran Biaya Pelayanan \\
\hline 11 & Kepastian Biaya \\
\hline 12 & Kepastian Jadwal Pelayanan \\
\hline 13 & Kenyamanan \\
\hline 14 & Keamanan \\
\hline
\end{tabular}


INOBIS: Jurnal Inovasi Bisnis dan Manajemen Indonesia

Volume 1, Nomor 3, Juni 2018

Joeliaty; Yevis Marty Oesman

Selanjutnya, kuadran III, yaitu kuadran yang menggambarkan posisi kinerja dan harapan yang rendah. Indikator tersebut adalah; (1) persyaratan pelayanan dan (2) kedisplinan petugas pelayanan. Dari kedua indikator ini pengguna tidak mendapatkan kepuasan, karena memang penggunapun tidak berharap banyak, mengingat pesyaratan pelayanan harus dipenuhi oleh pengguna, sementara kedisplinan petugas tidak begitu diharapkan, karena nampaknya kedisplinan petugas dimata pengguna memang kurang baik. Hal ini menuntut instansi untuk dapat meningkatkan kinerja, walaupun tidak begitu diharapkan, namun bila instansi telah menunjukkan kinerja yang baik, tentunya indikator inipun akan menjadi harapan yang tinggi pula.

Terakhir adalah kuadran IV. Kuadran ini menggambarkan posisi indikator yang memiliki tingkat harapan yang tinggi sementara kinerja yang dirasakan pengguna masih rendah. Indikator tersebut adalah; (1) prosedur pelayanan, (2) kecepatan petugas pelayanan, (3) keadilan mendapatkan pelayanan, dan (4) Kepastian jadwal pelayanan. Pengguna menaruh harapan yang tinggi terhadap keempat indikator pelayanan perinjinan ini, namun kinerja yang dirasakan oleh pengguna dibawah skor rata-rata. Hal ini mengindikasikan bahwa pengguna sangat kecewa dengan keempat indikator tersebut. Prosedur pelayanan yang diharapkan dapat diterima dengan mudah dan sederhana, namun ternyata tidak terealisasi, sederhana dan mudahnya prosedur pelayanan sehingga nampaknya kurang menjadi perhatian petugas, sehingga hal ini dianggap sepele, sementara indikator ini sangat diharapkan pengguna untuk mendapat perhatian yang tinggi oleh petugas. Begitu pula dengan indikator keadilan mendapatkan pelayanan dan kepastian jadwal pelayanan yang sangat diharapkan oleh pengguna, namun ternyata petugas tidak melayanai dengan adil dan tidak menepati janjinya atau tidak sesuai dengan jadwal yang telah ditentukan. Sehingga pengguna harus berulang-ulang dating ke kantor pelayanan perizinan. Innstansi pelayanan perizinan dituntut untuk memperhatikan implementasi dari indikator tersebut, jika hal ini dibiarkan, maka pengguna akan semakin tidak puas, tidak percaya, dan image atau citra instansi di mata pengguna akan sangat tidak baik.

\section{Kesimpulan dan Saran}

\subsection{Kesimpulan}

Berdasarkan hasil penelitian mengenai tingkat kepuasan terhadap pelayanan perijinan yang dilakukan oleh Kota Bandung maka dapat dilihat dari 14 indikator berikut :

1. Prosedur Pelayanan. Indikator ini menduduki posisi kuadran I baik dilihat dari kinerja, harapan maupun tingkat kepentingan. Hal ini menggambarkan bahwa prosedur pelayanan perijinan yang mudah dan sederhana dinilai sangat penting dan pengguna menaruh harapan yang tinggi, namun pada kenyataannya pengguna menilai kinerja yang masih rendah. Artinya instansi pemberi pelayanan perijinan belum dapat memberikan kepuasan, sementara indikator ini sangat penting bagi pengguna, sehingga instansi dituntut untuk dapat memberikan perhatian yang serius terhadap indikator prosedur pelayanan perijinan.

2. Persyaratan Perijinan. Indikator ini kinerja dan harapannya dinilai dibawah rata-rata oleh pengguna, artinya kinerja ini tidak memberikan kepuasan, namun demikian indikator ini dianggap cukup penting oleh pengguna, karena tidak mungkin pelayanan perijinan tanpa persyaratan yang harus dipenuhi oleh pengguna.

3. Kejelasan Petugas Pelayanan. Indikator ini baik dilihat dari kepentingan, harapan dan kinerja berada pada kuadran I, artinya indikator ini sudah menunjukkan kinerja yang 
INOBIS: Jurnal Inovasi Bisnis dan Manajemen Indonesia

Volume 1, Nomor 3, Juni 2018

Joeliaty; Yevis Marty Oesman

tinggi, tapi harapan dan kepentingan pengguna terhadap indikator ini di bawah rata-rata. Artinya pengguna sangat puas, namun indikator ini tidak begitu penting, sehingga pengguna merasa petugas terlalu berlebihan dalam memberikan informasi yang sebenarnya sudah dan mudah didapat oleh pengguna.

4. Kedisiplinan Petugas. Indikator ini memiliki kinerja yang rendah dan harapan pengguna terhadap indikator inipun rendah. Hal ini mengindikasikan bahwa pengguna sudah tidak peduli apakah mereka akan puas atau tidak dengan kedisplinan petugas, namun pengguna masih menilai bahwa indikator ini sangat penting. Karena petugas yang memiliki kedisiplinan yang rendah tentunya akan menujukkan bahwa isntasi tersebut memiliki citra yang tidak baik.

5. Tanggungjawab Petugas Pelayanan. Indikator ini menduduki posisi di kuadran II, baik tingkat kiner, harapan maupun kepentingan. Artinya Tanggungjawab petugas merupakan indikator yang penting bagi pengguna dan pengguna manaruh harapan yang tinggi dan ternyata petugas telah menunjukkan tanggungjawabnya yang tinggi pada pengguna, sehingga masyrakat merasa puas terhadap indikator ini. Sehingga instansi dituntut untuk dapat meningkat rasa tanggungjawab pada petugas pelayanan perijinan ini.

6. Kemampuan Petugas Pelayanan. Indikator ini dinilai pengguna sudah tinggi namun harapan pengguna rendah terhadap indikator ini, mengingat kemampuan yang dimiliki petugas sudah menjadi keharusan. Walaupun demikian pengguna menilai bahwa kamampuan yang handal adalah hal yang penting yang harus dimiliki oleh petugas pelayanan perijinan, sehingga yang menjadi tugas instansi adalah bagaimana agar kamapuan ini juga menjadi suatu indikator yang diharapkan oleh pengguna, sehingga petugas dapat terus meningkatkan kemampuannya, jangan puas dengan apa yang sudah dimiliki.

7. Kecepatan Petugas Pelayanan. Indikator ini mendapat sorotan yang begitu besar, pengguna menaruh tingkat kepentingan dan harapan yang tinggi, namun kinerja kecepatan petugas dinilai masih rendah. Artinya pengguna tidak puas atau kecewa terhadap indikator ini. Instansi dituntut untuk lebih memperhatikan daya tanggap, kepedulian, keseriusan dan ketrampilan petugas dalam memberikan pelayanan perijinan kepada pengguna.

8. Keadilan mendapatkan Pelayanan. Indikator ini juga mendapat perhatian yang begitu besar, mengingat pengguna menaruh tingkat kepentingan dan harapan yang tinggi, sementara kinerja keadilan mendapatkan pelayanan dinilai masih rendah. Artinya pengguna belum merasa puas atau kecewa terhadap pelayanan yang adil, pengguna merasa petugas menbeda-bedakan pelayanan terhadap pengguna. Indikator ini menuntut instansi pelayanan perizinan untuk lebih memperhatikannya.

9. Kesopanan dan keramahan Petugas Pelayanan. Indikator ini dinilai baik oleh pengguna dan penggunapun memiliki harapan yang tinggi. Artinya pengguna berharap petugas pelayanan perizinan dapat melayani dengan ramah dan sopan, dan pengguna sudah merasa puas. Namun indikator ini tidak menjadi hal yang penting bagi pengguna, karena hal itu sudah menjadi suatu keharusan bagi petugas pelayanan apapun.

10. Kewajaran Biaya. Indikator ini berada pada posisi dimana tingkat kinerja sudah tinggi, harapan dan tingkat kepentinganpun tinggi. Artinya pengguna menaruh harapan bahwa biaya untuk pelayanan perizinan dikenakan biaya yang wajar dan indikator ini sangat penting bagi pengguna. Dalam hal ini pengguna sudah merasa puas, namun Instansi dituntut untuk selalu memperhatikan indikator ini. 
INOBIS: Jurnal Inovasi Bisnis dan Manajemen Indonesia

Volume 1, Nomor 3, Juni 2018

Joeliaty; Yevis Marty Oesman

11. Kepastian Biaya. Indikator ini juga berada pada posisi yang sama dengan indikator kewajaran biaya, dimana tingkat kinerja sudah tinggi, harapan dan tingkat kepentinganpun tinggi. Artinya pengguna sudah merasa puas, namun tetap menaruh harapan bahwa kepastian biaya untuk pelayanan perizinan sudah ada tarip yang jelas, tidak ada lagi tambahan biaya yang lainnya. indikator ini sangat penting bagi pengguna. Instansi dituntut untuk selalu memperhatikan indikator ini.

12. Kepastian Jadwal Pelayanan. Indikator ini memiliki penialai kinerja yang rendah, sementara tingkat harapan dan kepentingan dinilai tinggi. Hal ini mengindikasikan bahwa pengguna merasa kecewa, karena petugas belum dapat memberikan kepastian jadwal pelayanan yang jelas dan konsisten. Jadwal dengan kinerja pelayanan tidak sesuai. Sementara indikator ini sangat diharapkan dan dinilai penting bagi pengguna, sehingga instansi dituntut untuk dapat lebih memberikan perhatiang yang tinggi terhadap indikator ini, yang pada akhirnya pengguna akan merasa puas.

13. Kenyamanan. Pengguna merasakan sangat puas dengan indikator ini, mengingat kantor yang megah dan luas, namun kenyamanan ini tidak begitu menjadi harapan dan kepentingan bagi pengguna atau tingkat harapan dan kepentingannya rendah, mengingat pengguna hanya sebentar di kantor, hanya menyerahkan persyaratan dan tidak ingin berlama-lama di kantor pelayanan tersebut. Sehingga dimasa dating instansi dapat mengalihkan dana kepada indikator yang lebih penting.

14. Keamanan. Indikator ini dirasakan sudah puas. Namun pengguna tidak merasa penting dengan keamanan, walaupun demikian pengguna masih berharap adanya keamanan. Karena dimanapun kita berada tentunya berharap ada pada lingkungan yang aman.

\subsection{Saran}

Berdasarkan kesimpulan dari penelitian yang dilakukan, maka dapat diajukan saran mengenai tingkat kepuasan terhadap pelayanan perijinan yang dilakukan oleh Kota Bandung yaitu terdapat 6 poin yang disarankan, yaitu :

1. Dari segi Prosedur Pelayanan, kinerja instansi pemberi pelayanan perijinan belum dapat memberikan kepuasan, sementara indikator ini sangat penting bagi pengguna, sehingga instansi dituntut untuk dapat memberikan perhatian yang serius terhadap indikator prosedur pelayanan perijinan.

2. Tanggungjawab petugas pelayanan merupakan indikator yang penting bagi pengguna dan pengguna manaruh harapan yang tinggi dan ternyata petugas telah menunjukkan tanggungjawabnya yang tinggi pada pengguna, sehingga pengguna merasa puas terhadap indikator ini. Sehingga instansi dituntut untuk dapat meningkat rasa tanggungjawab pada petugas pelayanan perijinan ini.

3. Kemampuan yang handal adalah hal yang penting yang harus dimiliki oleh petugas pelayanan perijinan, sehingga yang menjadi tugas instansi adalah bagaimana agar kamapuan ini juga menjadi suatu indikator yang diharapkan oleh pengguna, sehingga petugas dapat terus meningkatkan kemampuannya.

4. Dari segi Kecepatan Petugas Pelayanan, pengguna tidak puas atau kecewa terhadap indikator ini. Instansi dituntut untuk lebih memperhatikan daya tanggap, kepedulian, keseriusan dan ketrampilan petugas dalam memberikan pelayanan perijinan kepada pengguna.

5. Dari segi Keadilan mendapatkan pelayanan yang sama, pengguna belum merasa puas atau kecewa terhadap pelayanan yang adil, pengguna merasa petugas menbeda-bedakan 
INOBIS: Jurnal Inovasi Bisnis dan Manajemen Indonesia

Volume 1, Nomor 3, Juni 2018

Joeliaty; Yevis Marty Oesman

pelayanan terhadap pengguna. Indikator ini menuntut instansi pelayanan perizinan untuk lebih memperhatikannya.

6. Dalam hal Kepastian Jadwal Pelayanan, pengguna merasa kecewa karena petugas belum dapat memberikan kepastian jadwal pelayanan yang jelas dan konsisten. Jadwal dengan kinerja pelayanan tidak sesuai. Sementara indikator ini sangat diharapkan dan dinilai penting bagi pengguna, sehingga instansi dituntut untuk dapat lebih memberikan perhatiang yang tinggi terhadap indikator ini, yang pada akhirnya pengguna akan merasa puas.

\section{Daftar Pustaka}

Husein Umar, 2003, Metode Riset Bisnis. Jakarta : PT.Gramedia Pustaka Utama.

Kaplan, Robert M \& Saccuzzo, Dennis P, 2005, Psycological testing : principles, applications, and issues. $6^{\text {th }}$ editions, Thomson. Canada.

Keputusan Menteri Pendayagunaan Aparatur Negara (Kepmen PAN) Nomor:

KEP/25/M.PAN/2/2004

Kotler, Philip \& Keller, Kevin Lane, 2012, Marketing Management. Pearson International Edition, 14th Edition, New Jersey : Pearson Prentice Hall International, Inc

Malhotra, Naresh K, 2010, Marketing Research : an applied orientation, Prentice Hall. London.

Pedoman Umum Penyelenggaraan Pelayanan Publik. 2003 